\title{
Influence of wastewater on zooplankton communities in the Daugava River upstream and downstream of Daugavpils over the last 50 years
}

\author{
R. Deksne $e^{(1,2)}$
}

Received December 4, 2010

Revised April 1, 2011

Accepted May 31, 2011

\section{ABSTRACT}

Key-words: large river, zooplankton, hydrological regime, pollution

\begin{abstract}
During expeditions to the section of the Daugava River from Surozha in Belarus to Dunava in Latvia in 2008, and during expeditions to the Kraslava-Dunava section in 2009, zooplankton were sampled. Quantitative characteristics, the relation of zooplankton taxonomic groups, the saprobity index and species diversity (Shannon-Wiener index) were employed for the analysis of zooplankton community structure in the Daugava River. The results were compared with the Daugava zooplankton findings of the research carried out by Škute in 1962-1968 in similar sections of the river. Both in 1962-1963 and in 2005-2009, the base complex of the Daugava River zooplankton comprised cosmopolitan species; as for the diversity of species, the leading group of organisms was Rotifera.

A tendency for decrease in the diversity of species was recorded. Relevant changes were recorded in the structure of taxa. The Daugava River is polluted by Daugavpils' wastewater; however, the untoward influence of pollution on zooplankton is observed only in years and in seasons with low water level and discharge. Decrease in the amount of zooplankton occurs not only in the dominant species, but also in the decrease or even disappearance of oligosaprobes.
\end{abstract}

\section{RÉSUMÉ}

Influence des eaux usées sur les communautés zooplanctoniques dans la rivière Daugava en amont et en aval de Daugavpils au cours des 50 dernières années

Mots-clés :

fleuve,

zooplancton,

régime

hydrologique, pollution
Pendant les expéditions à la partie de la rivière Daugava allant de Surozha en Biélorussie à Dunava en Lettonie en 2008, et lors des expéditions à la section Kraslava-Dunava en 2009, le zooplancton a été échantillonné. Les caractères quantitatifs, les groupes taxonomiques du zooplancton, l'indice saprobie et la diversité spécifique (indice de Shannon-Wiener) ont été utilisés pour l'analyse de la structure de la communauté du zooplancton dans la rivière Daugava. Les résultats ont été comparés avec les résultats des recherches effectuées par Škute en 1962-1968 sur le zooplancton de la Daugava dans des sections similaires de la rivière. En 1962-1963 comme en 2005-2009, le complexe de base du zooplancton de la rivière Daugava est composé d'espèces cosmopolites, et pour la richesse

(1) Rezekne Higher Education Institution Latgale Sustainable Development Research Institute, 
spécifique, les rotifères arrivent en tête. Une tendance à la diminution de la diversité des espèces a été enregistrée. Des changements significatifs ont été enregistrés dans la structure des taxons. La rivière Daugava est polluée par les eaux usées de Daugavpils, mais l'influence fâcheuse de la pollution sur le zooplancton est observée seulement dans les années et les saisons avec faible niveau d'eau et de décharge. La diminution de la quantité de zooplancton se produit non seulement pour les espèces dominantes, mais aussi par la diminution ou même la disparition des oligosaprobes.

\section{INTRODUCTION}

The Daugava River (Zapadnaja Dvina) is a river in the north of Eastern Europe rising in the Valdai Hills, Russia, and flowing through Russia, Belarus and Latvia into the Gulf of Riga, an arm of the Baltic Sea. The total length of the river is $1005 \mathrm{~km}, 352 \mathrm{~km}$ of which or $35 \%$ of its total length fall to Latvia (The summary of overground waters' quality, 2003). Its catchment area is about $87900 \mathrm{~km}^{2}$ in the territories of five countries (Russia, Belarus, Lithuania, Estonia and Latvia), and $24700 \mathrm{~km}^{2}$ or $29 \%$ of the total watershed belong to Latvia (Kavacs, 1994). According to the Strahler stream order classification, the Middle and Lower Daugava in Latvia belongs to the 7th-9th order rivers (Gruberts, 2007).

Geologically the Daugava River basin is covered by glacial deposits to depths of 200 metres. The greatest part of these deposits consists of Weichselian (Latvian) Glacial, characterised by till, sandy till and glaciolacustrine sand. After the Ice Age alluvial matters were deposited (Kurss and Stinkule, 1997).

At its source (the Lake Dvineca), the river is only 6 to $8 \mathrm{~m}$ wide, but further on the width of the valley reaches $50 \mathrm{~m}$ in some places. Upstream and downstream of the city of Vitebsk (Belarus), the river flows through dolomite rocks, and there are many rapids, with the depth varying from 0.8 to $3 \mathrm{~m}$. On the Latvian border, the river runs along the $0.5-\mathrm{km}$-wide ancient valley and the riverbed is up to $200 \mathrm{~m}$ wide. The section from Krāslava to Daugavpils is highly curved and has many rapids. The longitudinal gradient changes from 0.10 to $0.15 \mathrm{~m} / \mathrm{km}$, and the stream velocity from $0.3 \mathrm{~m} / \mathrm{sec}$ to $0.7 \mathrm{~m} / \mathrm{sec}$ in most sections. Downstream of Daugavpils, the river is slow, with gently sloping banks and wide floodplains. The riverbed is rather sandy, with typical sandbanks very often causing ice-jams in winter and spring (LU agency, "LU Institute of Biology", 2007). In spring a rise in the Daugava River's water level is typical, so that in Eastern Latvia high water can reach 13 metres. Noticeable high water in incessant rains is also observed, when the water level can increase by 2.5 metres, as well as this high water being blown to the Daugava mouth (The summary of overground waters' quality, 2003).

About half of the total mean annual amount of the Daugava runoff is formed during the spring floods (Briede et al., 2001). The largest discharge is usually observed in April, during the intense snowmelt. The mean largest discharge $\left(1600 \mathrm{~m}^{3} \cdot \mathrm{s}^{-1}\right)$ is usually observed the same time. The beginning of spring floods is usually associated with a fast break-up of the ice cover, which forms in the river in late December and reaches its maximum thickness at the end of March (Briede et al., 2004). The floods continue for 3-4 months depending on the year. The highest water level of the year is usually above that observed during the spring icedrift period, except for the years when massive ice-jams block the riverbed, therefore producing unusually high water levels further upstream.

The Daugava River plays an important role in the life of the Latvian population since it is not only the longest river in Latvia and one of the most significant natural resources, which is highly important for the well-balanced position of development of the Latvian regions, but it is also a symbol of Latvian national heritage value and a symbol of psychological value. The Daugava is the most important river in Latvia, not only due to its historical importance, but also as a source of energy and as a reservoir for drinking water for Riga. Water quality in the Daugava largely depends on the pollution from outside (e.g. in 2000 , of nitrogen carried by 
the Daugava River basin into the Baltic sea, $73 \%$ was caused by cross-border pollution): also, there have been pollution precedents due to emergency situations in Belarus, in the Novopolock Chemistry plant in 1990, the damage to the oil pipeline in Belarus in 1981, and also the diesel leak in 2007 (Kl̦avinsš et al., 2008). At the same time, the Daugava River has the biggest influence on the water quality of the Riga Gulf (the Daugava waters provide up to $66 \%$ of phosphorus runoff, $49 \%$ of total nitrogen runoff, $53 \%$ of mineral substances and $64 \%$ of organic substances runoff), (LU agency, "LU Institute of Biology", 2007). Therefore, there is a necessity to be aware of and to assess the current pollution load.

The indicative role of zooplankton in the study of pollution processes is shown in some scientific studies. The potential of zooplankton as a bio-indicator is very high because their growth and distribution are dependent on some abiotic (e.g., temperature, salinity, stratification, pollutants) and biotic parameters (e.g., food limitation, predation, competition) (Lazareva, 2010; Escribano and Hidalgo, 2000). However, some authors (Beach, 1960; Ivanova, 1976a) indicate that the use of zooplankton in assessing river water quality is insignificant, because in the river flow a sufficiently stable cenosis is not formed, which could be characteristic of the definite river leg. Nonetheless, a great number of authors are drawing attention to the possibilities of the use of zooplankton in assessing river water quality (Whitton, 1975; Kutikova, 1976; Demenik, 1988; Marneffe et al., 1996; Vandish, 2000; Krylov, 2005; Bakaeva and Nikanorov, 2006; Mathivanan et al., 2007; Ferdous and Muktadir, 2009; Mulani et al., 2009; Vanjare et al., 2010).

The aim of the following study is to clarify the influence of Daugavpils city's wastewater on zooplankton communities and at the same time to assess the ecological situation of the Daugava River near the city of Daugavpils.

\section{MATERIAL AND METHODS}

During expeditions to the Daugava River section from Surozha in Belarus to Dunava in Latvia (21 sites) in 2008, and during expeditions to the Kraslava-Dunava section (13 sampling sites) in 2009, zooplankton were sampled at the right and left banks, as well as in the middle of the river (Figure1, Table I).

For R. Škute's zooplankton investigations samples were collected in a similar river section from Beshenkovichi (Belarus) to Jēkabpils (Latvia) in July and August 1962 and 1963. Sampling was performed at both banks as well as in the middle flow, at 28 sites in total. In the same years zooplankton samples were also collected monthly from the Latvian border Jekkabpils section of the Daugava River, at 10 sites in total.

Samples of zooplankton were collected by filtering 100 I of river water with a $65-\mu \mathrm{m}$ meshsize plankton net. This net mesh size was selected because a similar one had been used during the study conducted in 1962-1968 by Škute. Collected samples were fixed in 4\% formalin. A Carl Zeiss light microscope was used for the analysis of zooplankton; three subsamples (2 mL each) were examined at 100-400x magnification. The identification of Rotifera, Cladocera and Copepoda taxa was the aim of the qualitative study, for which zooplankton determinants were used (Borutsky, 1960; Manuilova, 1964; Kutikova, 1970).

Quantitative characteristics (abundance, biomass, number of taxa) and the relation of zooplankton taxonomic groups and species diversity (Shannon-Wiener index derivative $\mathrm{N}_{1}$ according to the number of organisms) were employed for the analysis of zooplankton community structure in the Daugava River.

Species diversity was calculated according to the Shannon-Wiener index (Shannon, 1948; Krebs, 1999):

$$
H^{\prime}=\sum_{i=1}^{s}\left(p_{i}\right)\left(\log _{2} p_{i}\right)
$$



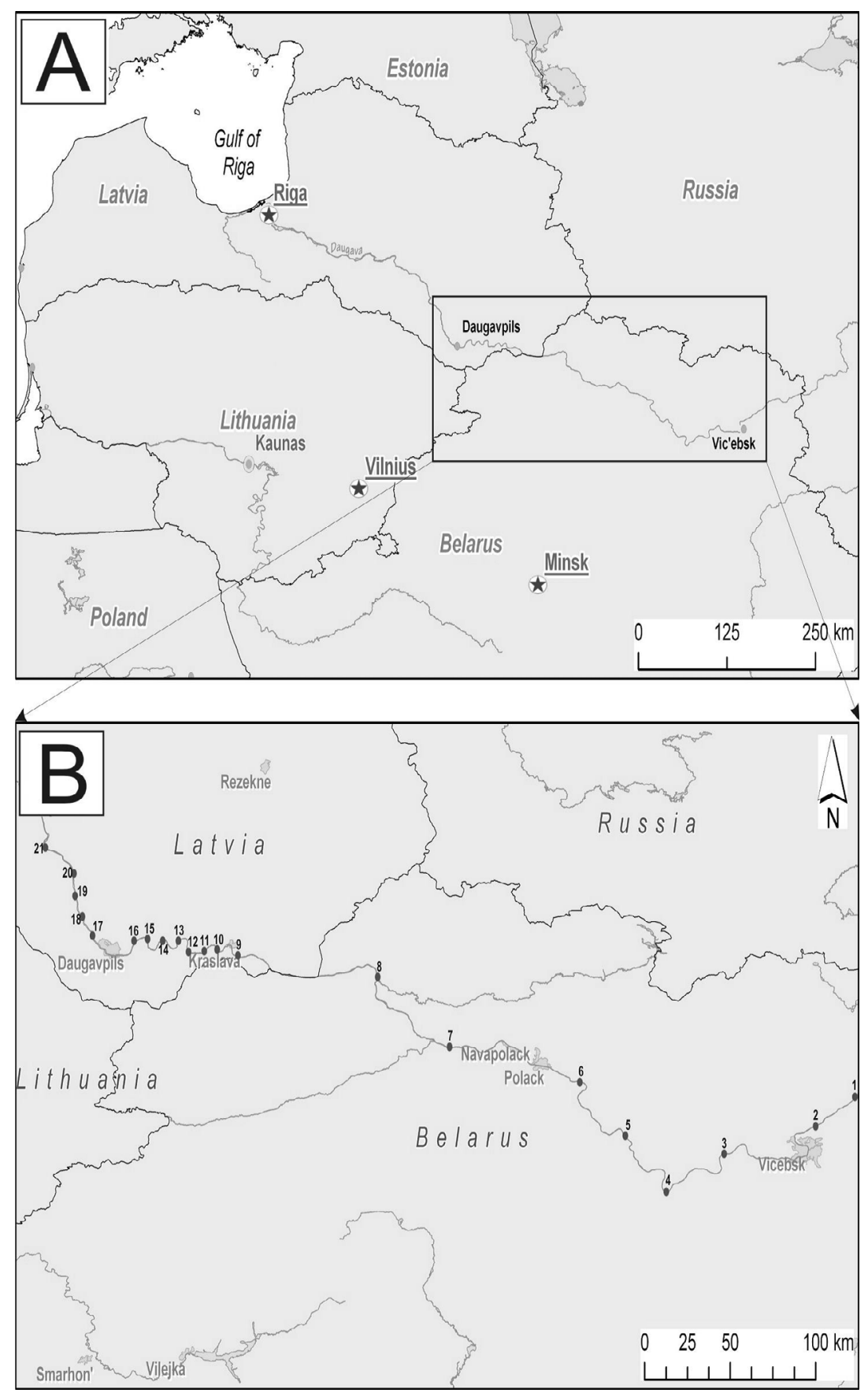

Figure 1

Sampling sites in the Daugava during the 2008-2009 expedition.

Figure 1.

Sites d'échantillonnage dans la Daugava lors de l'expédition 2008-2009.

where $S$ is the number of species and $p_{i}$ is the proportion of individuals of the $i$ th species to the total number of species.

The Shannon-Wiener index may be expressed in another form (MacArthur, 1965), in units of the number of species as

$$
N_{1}=e^{H^{\prime}}
$$


Table I

GPS coordinates of sampling sites and dates.

Tableau I

Coordonnées GPS des sites d'échantillonnage et dates d'échantillonnage.

\begin{tabular}{|l|c|c|c|c|}
\hline $\begin{array}{l}\text { Sampling site } \\
\text { No. 16: 10 km upstream } \\
\text { of Daugavpils }\end{array}$ & $\begin{array}{c}\text { Geographic } \\
\text { latitude }\end{array}$ & $\begin{array}{c}\text { Geographic } \\
\text { longitude }\end{array}$ & 2008 & 2009 \\
\hline $\begin{array}{l}\text { No. 17: 1.5 km downstream } \\
\text { of Daugavpils }\end{array}$ & $55^{\circ} 53.311^{\prime} \mathrm{N}$ & $026^{\circ} 28.401^{\prime} \mathrm{E}$ & 2 August & 25 August \\
\hline $\begin{array}{l}\text { No. 18: 10 km downstream } \\
\text { of Daugavpils }\end{array}$ & $55^{\circ} 57.326^{\circ} \mathrm{N}$ ' & $026^{\circ} 24.271^{\prime} \mathrm{E}$ & 2 August & 25 August \\
\hline
\end{tabular}

where $e=2, H^{\prime}=$ Shannon-Wiener function and $N_{1}=$ number of equally common species that would produce the same diversity as $H^{\prime}$.

Hill (1973) recommends using $N_{1}$ rather than $H^{\prime}$ because units (the number of species) are more clearly understandable to ecologists. Therefore, $N_{1}$ is used in the present research.

The analysis of similarities across sites and years was carried out using the Renkonen index. The saprobity index $S$ was calculated according to Sladechek's method, using the species bioindicators catalogue created by P. Cimdinš̌ for the Latvian conditions (Cimdinš et al., 1995). The results obtained were compared with the findings of Škute's studies carried out in 1962-1968 in a similar section of the Daugava River, Beshenkovichi (Belarus) - Jēkabpils (Latvia) (Škute, 1971, 1976).

In order to clarify the influence exerted by Daugavpils city's wastewater on the zooplankton communities and the Daugava River's ecological condition in general, in this study the sampling sites at the Daugava River, $10 \mathrm{~km}$ upstream (No. 16), $1.5 \mathrm{~km}$ downstream (No. 17) and $10 \mathrm{~km}$ downstream of the Daugavpils purification plant (No. 18) (Figure1, Table I), are analysed in detail.

\section{RESULTS AND DISCUSSION}

The studies of the Beshenkovichi (Belarus) - Jēkabpils (Latvia) section of the Daugava River carried out by R. Škute in 1962 and 1963 reported a total of 147 zooplankton taxa which comprised 70 Rotifera, 48 Cladocera and 29 Copepoda taxa (Škute, 1971): typical plankton organisms constituted $29.7 \%$, and facultative plankton organisms $70.8 \%$ of the abovementioned taxa (Škute, 1971). During the 2008-2009 studies of the Surozha (Belarus) Dunava (Latvia) section, 110 taxa were found, among which there were 60 Rotifera, 32 Cladocera and 18 Copepoda taxa (Table II).

Compared with the findings of the 1962-1963 studies, the total number of zooplankton taxa in 2008-2009 had decreased by 37 taxa. The observed changes in the structure of taxa are substantial: only 64 taxa were recorded in both studies; consequently, a total of 46 new taxa had appeared in 2008-2009, while 83 of the 147 taxa identified in 1962-1963 were not found (Table II).

Both in 1962-1963 and in 2008-2009, the base complex of the Daugava River zooplankton comprised cosmopolite species characterised by a wide distribution area. Plankton organisms commonly found in 1962-1963 were dominated by Brachionus urceolaris and Chydorus sphaericus, and facultative plankton organisms by Euchlanis dilatata, Philodina sp., Alona quadrangula and Ceriodaphnia affinis. Predominant among Rotifera in 1962-1963 were 


\section{Table II}

The total number of zooplankton taxa recorded in the Daugava in 1962-1963 and 2008-2009.

Tableau II

Nombre total de taxons zooplanctoniques enregistrés dans la Daugava en 1962-1963 et 2008-2009.

\begin{tabular}{|l|c|c|c|}
\hline Taxa & $\begin{array}{c}\text { Beshenkovichi-Jekabpils } \\
(1962-1963)\end{array}$ & $\begin{array}{c}\text { Surozha - Dunava } \\
(2008-2009)\end{array}$ & $\begin{array}{c}\text { Found in both } \\
\text { studies }\end{array}$ \\
\hline Rotifera & 70 & 60 & 32 \\
\hline Cladocera & 48 & 32 & 21 \\
\hline Copepoda & 29 & 18 & 11 \\
\hline Total & 147 & 110 & 64 \\
\hline
\end{tabular}

Euchlanis dilatata, Brachionus angularis, Brachionus urceolaris and Philodina sp., and in 2008-2009, Euchlanis dilatata and Brachionus quadridentatus; in 1962-1963 Cladocera were dominated by Alona quadrangularis, Ceriodaphnia affinis, Chydorus sphaericus and Macrothrix laticornis, and in 2008-2009 by Sida crystallina, Ceriodaphnia reticulata and Chydorus ovalis. According to the findings of both the 1962-1963 and 2008-2009 investigations, nauplii were prevalent among Copepoda.

The qualitative and quantitative distribution of zooplankton in the river lengthwise and across the river profile both in 1962-1963 and in 2008-2009 was highly variable. In the middle of the river, where the speed of the flow is higher, the smallest total number of organisms was recorded.

The changes mentioned above could be related to the consequences of climate change. Climate change resulting in warmer temperatures and a changed hydrological regime would alter the flux of water, heat and nutrients and thereby influence the seasonal dynamics of phytoplankton composition, responses of zooplankton, fish reproduction and overall bioproduction (Hauer et al., 1997).

According to study results, the mean annual air temperature in Daugavpils has risen by about $1.3{ }^{\circ} \mathrm{C}$ during the last 50 years. Meanwhile, the mean annual precipitation has remained the same, whereas the mean thickness of the snow cover has significantly decreased (Gruberts, 2009).

The mean annual discharge of the Daugava River in Daugavpils has remained almost the same since the beginning of hydrological records in 1960. Meanwhile, the highest annual discharge has obviously decreased, while the lowest annual discharge has increased (Figure 2) (Deksne et al., 2010). Such changes could be explained by shorter winters and an increased discharge during the winter low water period over the last few decades (Kl̦avinš et al., 2008).

A significant amount of pollution flows into the Daugava River within the Daugavpils city administrative territory. According to the Central Statistical Bureau data, on January 1, 2009, Daugavpils city had a population of 104857 . Before 2009 the Daugavpils wastewater purification plant operated using mechanical and biological purification, which does not ensure complete wastewater purification. On September 18, 2009, the advanced Daugavpils city wastewater purification plant was opened. Since the project implementation the amount of phosphorus in wastewater has decreased nearly 5 times, which ensures compliance with the EU directive (The Ministry of the Environment, 2009). In order to ascertain the impact exerted by Daugavpils city's wastewater on zooplankton communities and the ecological condition of the Daugava River in general, sampling sites at the Daugava River - $10 \mathrm{~km}$ upstream, $1.5 \mathrm{~km}$ downstream and $10 \mathrm{~km}$ downstream of Daugavpils city's purification plant are further compared. 


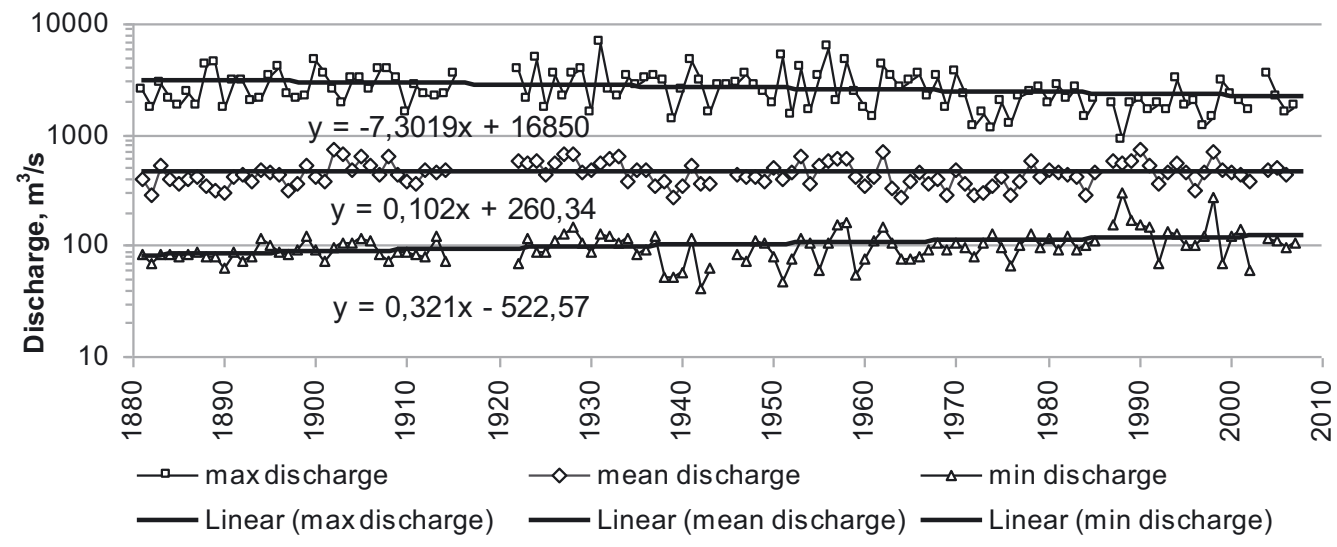

Figure 2

The mean, highest and lowest annual discharges of the Daugava River near Daugavpils, 1960-2008 (The Global Runoff Data Centre, 56068 Koblenz, Germany, 2010).

Figure 2

Débit moyen, maximum et minimum annuel de la rivière Daugava près de Daugavpils, 1960-2008.

Comparing the 1962 and the 2008-2009 studies the total taxa number in the investigated section of the river has not substantially changed. In 200914 taxa were found, in 2008 28 taxa, and in 196225 taxa (Škute, 1971). However, there are substantial qualitative changes - only 12 taxa were found both in the 1962 and the 2008-2009 studies (Table III). It must be added that 6 taxa: Filinia longiseta, Kellicottia longispina, Scaridium longicaudum, Synchaeta tremula, Trichocerca capucina and Acroperus harpae, which were not found in the compared sites in 2008-2009, were found in the other sampling sites in 2008-2009 in the Daugava River. While 8 taxa: Lecane lunaris, Trichocerca rattus, Chydorus ovalis, Eurycercus lamellatus, Pleuroxus trigonellus, Rhynchotalona rostrata, Scapholeberis mucronata and Simocephalus vetulus, which were not found in sampling sites in 1962, were found in the other sampling sites in 1962 in the Daugava River (Škute, 1971).

$77 \%$ of the species found in the investigated section of the Daugava River are indicator species of saprobity, which is a sufficient amount to consider the river's pollution level according to zooplankton. Kutikova (1976) indicates that it is difficult to consider the river saprobity if there are few indicator species of saprobity in the river.

The studies of the 1950s and 60s on the Daugava River showed that concentrations of dissolved substances and biogenic elements are tightly connected with the river water flow rate. Construction of large industrial enterprises and new residential buildings without the necessary wastewater purification activities taking place have exerted a substantial impact on the river ecosystems and populations of live organisms downstream of the towns Krāslava, Daugavpils, Līvāni and Jēkabpils, but especially downstream of Riga (Auniņš, 1963; Matisone, 1965).

In the summer of 1962 the mean air temperature did not exceed $16-17{ }^{\circ} \mathrm{C}$, and the abundance of zooplankton was lower than in 1963 when the temperature was higher and the water level was lower (Table IV). In 1962 the abundance of zooplankton downstream of the Daugavpils city purification plant noticeably increased, mainly due to breeding of Euchlanis dilatata and Sida crystallina in large quantities on the right bank (Škute, 1971). The increased abundance of zooplankton could be explained by the fact that the summer of 1962 was characterised by a high water level, the average annual flow rate being $721 \mathrm{~m}^{3} \cdot \mathrm{s}^{-1}$ (Table IV). The right bank downstream of Daugavpils is rich in macrophytes and due to a meander in this section of the river, the main river flow leans towards the middle of the river and its left bank; thereby, the right bank of the Daugava has not been affected by the Daugavpils wastewater. Thus, downstream of Daugavpils a $\beta$-mesosaprobic zone was 


\section{Table III}

Zooplankton taxa in 1962 and 2008-2009 $10 \mathrm{~km}$ upstream (U) and $1.5 \mathrm{~km}$ downstream (D) of the Daugavpils city purification plant.

\section{Tableau III}

Taxons zooplanctoniques en 1962 et 2008-2009, $10 \mathrm{~km}$ en amont (U) et à 1,5 km en aval (D) de l'usine d'épuration de la ville de Daugavpils.

\begin{tabular}{|c|c|c|c|c|c|c|}
\hline \multirow[t]{2}{*}{ Taxa } & \multicolumn{2}{|c|}{1962} & \multicolumn{2}{|c|}{2008} & \multicolumn{2}{|c|}{2009} \\
\hline & $\mathrm{U}$ & D & $\mathrm{U}$ & D & $\mathrm{U}$ & D \\
\hline ROTIFERA & 10 & 12 & 10 & 10 & 3 & 5 \\
\hline Asplanchna priodonta Gosse, 1850 & & & $\mathrm{x}$ & & & \\
\hline Ascomorpha ecaudis Perty, 1850 & & & & $x$ & & \\
\hline Bdeloid & & & $x$ & $\mathrm{x}$ & & $x$ \\
\hline Brachionus angularis angularis Gosse, 1851 & $\mathrm{x}$ & & & $\mathrm{x}$ & $\mathrm{x}$ & \\
\hline Brachionus quadridentatus quadridentatus Hermann, 1783 & $\mathrm{x}$ & $\mathrm{x}$ & $x$ & $\mathrm{x}$ & & $x$ \\
\hline Brachionus pala Eghrenberg, 1838 & & $\mathrm{x}$ & & & & \\
\hline Brachionus urceolaris O.F. Müller, 1773 & & $\mathrm{x}$ & & & & \\
\hline Euchlanis dilatata Ehrenberg, 1832 & $\mathrm{x}$ & $x$ & $\mathrm{x}$ & $\mathrm{x}$ & $\mathrm{x}$ & $\mathrm{x}$ \\
\hline Filinia longiseta Ehrenberg, 1834 & $\mathrm{x}$ & & & & & \\
\hline Keratella cochlearis cochlearis Gosse, 1851 & & $\mathrm{x}$ & $\mathrm{x}$ & & $\mathrm{x}$ & \\
\hline Keratella quadrata quadrata O.F. Müller, 1786 & $\mathrm{x}$ & $\mathrm{x}$ & & $\mathrm{x}$ & & \\
\hline Kellicottia longispina Kellicott, 1879 & $\mathrm{x}$ & & & & & \\
\hline Lacinularia flosculosa O.F. Müller, 1773 & $\mathrm{x}$ & & & & & \\
\hline Lecane Iuna Iuna O.F. Müller, 1776 & $x$ & $\mathrm{x}$ & $\mathrm{x}$ & & & \\
\hline Lecane lunaris Ehrenberg, 1832 & & & & $x$ & & $\mathrm{x}$ \\
\hline Lepadella ovalis O.F. Müller, 1896 & & & $\mathrm{x}$ & $\mathrm{x}$ & & \\
\hline Philodina sp. & $\mathrm{x}$ & $\mathrm{x}$ & & & & \\
\hline Scaridium Iongicaudum O.F. Müller, 1786 & $\mathrm{x}$ & $\mathrm{x}$ & & & & \\
\hline Synchaeta tremula O.F. Müller, 1786 & & $\mathrm{x}$ & & & & \\
\hline Synchaeta sp. & & $x$ & $x$ & & & \\
\hline Trichocerca capucina Wierzejskiet, Zacharias, 1893 & & $\mathrm{x}$ & & & & \\
\hline Trichocerca cylindrica Imhof, 1891 & & & & $x$ & & \\
\hline Trichocerca rattus O.F. Müller, 1776 & & & $\mathrm{x}$ & $\mathrm{x}$ & & $\mathrm{x}$ \\
\hline Trichotria pocillum O.F. Müller, 1776 & & & $x$ & & & \\
\hline CLADOCERA & 3 & 3 & 7 & 6 & 2 & 3 \\
\hline Acroperus harpae Baird, 1834 & $\mathrm{x}$ & & & & & \\
\hline Bosmina longirostris O.F Müller,1785 & $\mathrm{x}$ & $x$ & $\mathrm{x}$ & & & \\
\hline Ceriodaphnia reticulata Jurine, 1820 & & & & $\mathrm{x}$ & & $\mathrm{x}$ \\
\hline Chydorus ovalis Kurz, 1875 & & & $\mathrm{x}$ & $\mathrm{x}$ & & \\
\hline Chydorus sphaericus O.F. Müller,1785 & $x$ & $\mathrm{x}$ & $x$ & $\mathrm{x}$ & & \\
\hline Diaphanasoma brachyurum Liévin, 1848 & & & & & $\mathrm{x}$ & \\
\hline Eurycercus lamellatus O.F. Müller, 1776 & & & $x$ & $x$ & & \\
\hline Polyphemus pediculus Linnaeus, 1761 & & & $\mathrm{x}$ & & & \\
\hline Pleuroxus trigonellus O.F. Müller, 1776 & & & $\mathrm{x}$ & & & \\
\hline Rhynchotalona rostrata Koch, 1841 & & & & $\mathrm{x}$ & & \\
\hline Scapholeberis mucronata O.F. Müller, 1776 & & & & & & $\mathrm{x}$ \\
\hline Sida crystallina O.F. Müller, 1776 & & $\mathrm{x}$ & $\mathrm{x}$ & & $\mathrm{x}$ & $\mathrm{x}$ \\
\hline Simocephalus vetulus O.F. Müller, 1776 & & & & $\mathrm{x}$ & & \\
\hline $\begin{array}{l}\text { COPEPODA } \\
\end{array}$ & 5 & 6 & 2 & 2 & 1 & 2 \\
\hline Acanthocyclops stygius Chopp, 1924 & & $\mathrm{x}$ & & & & \\
\hline Canthocamptus staphylinus Jurine, 1820 & & & & & & $\mathrm{x}$ \\
\hline Cyclops sp. & $x$ & $\mathrm{x}$ & & $\mathrm{x}$ & & \\
\hline Paracyclops fimbriatus Fischer, 1853 & $\mathrm{x}$ & & & & & \\
\hline Nauplii & $x$ & $x$ & $x$ & $x$ & $x$ & \\
\hline Copepodite & $x$ & $x$ & $x$ & & & $x$ \\
\hline TOTAL & 18 & 21 & 19 & 18 & 6 & 10 \\
\hline
\end{tabular}


Table IV

Hydro-meteorological conditions in the Daugava River in 1962-1968 and 2008 near Daugavpils.

Tableau IV

Conditions hydro-météorologiques sur la rivière Daugava en 1962-1968 et 2008 près de Daugavpils.

\begin{tabular}{|l|c|c|c|c|}
\hline Year & Month & $\begin{array}{c}\text { Mean water level above } \\
\text { Station's zero grade } \\
(85.81 \mathrm{~m}) \\
\mathrm{cm}\end{array}$ & $\begin{array}{c}\text { Max water level above } \\
\text { Station's zero grade } \\
(85.81 \mathrm{~m}) \\
\mathrm{cm}\end{array}$ & $\begin{array}{c}\text { Mean monthly } \\
\text { Water } \\
\text { temperature } \\
{ }^{\circ}\end{array}$ \\
\hline $\mathbf{1 9 6 2}$ & July & 305 & 541 & 17.3 \\
\hline $\mathbf{1 9 6 3}$ & August & 189 & 292 & 17.3 \\
\hline & July & -29 & 16 & 20.9 \\
\hline $\mathbf{1 9 6 4}$ & Jugust & -46 & -23 & 19.6 \\
\hline & July & -63 & -54 & 21.7 \\
\hline $\mathbf{1 9 6 6}$ & July & -69 & -63 & 18.1 \\
\hline & August & -32 & -26 & 20.4 \\
\hline $\mathbf{1 9 6 8}$ & July & -27 & -5 & 19.9 \\
\hline & August & -9 & 0 & 16.9 \\
\hline $\mathbf{2 0 0 8}$ & July & -33 & -14 & 18.9 \\
\hline & August & -59 & -42 & 21.3 \\
\hline $\mathbf{2 0 0 9}$ & July & -68 & -54 & 20.1 \\
\hline & August & 4 & 66 & 20.7 \\
\hline
\end{tabular}

formed: this is characterised by intensified growth of the abundance of zooplankton (Figure 4). Biological diversity according to the Shannon-Wiener index was similar in both places: upstream of Daugavpils - 6.0, and downstream of Daugavpils - 5.8.

The Daugava also had a high water level in summer 2009 (Table IV, Figure 3). The Daugava water balance in July 2009 was $115 \%$ of the norm. The mean flow rate was $300 \mathrm{~m}^{3} \cdot \mathrm{s}^{-1}$. In August 2009 the Daugava water balance was $103 \%$. The mean flow rate was $275 \mathrm{~m}^{3} \cdot \mathrm{s}^{-1}$. At the beginning of August in the Daugava the high water continued, having started at the end of July after heavy rains in the upper part of the river basin. The water level continued rising in the territory of Russia and Belarus until August 1-3, but in the Piedruja - Jekkabpils section until August 4-6. The total water level rise was 0.7-2.1 m. In August the mean water temperature was according to the norm. The highest water temperature in the Daugava was observed at the beginning of August; the maximum monthly water temperature reached $+21.6^{\circ} \mathrm{C}$. The lowest monthly water temperature in the Daugava was noticed during the period of 21 to 26 August: within the range of $+17.1 \ldots+17.5{ }^{\circ} \mathrm{C}$ (Latvian Environment, Geology and Meteorology Centre, 2008).

As in 1962, in 2009 the abundance of zooplankton downstream of the Daugavpils purification plant also noticeably increased (Figure 4), mainly due to breeding of Euchlanis dilatata and Sida crystallina in large quantities at the right bank. The Shannon-Wiener index value changed from upstream of Daugavpils - 2.5 to downstream of Daugavpils - 2.6. Consequently, in years and seasons with high flow rates, a negative effect of Daugavpils' wastewaters on the Daugava zooplankton communities was not recorded. 


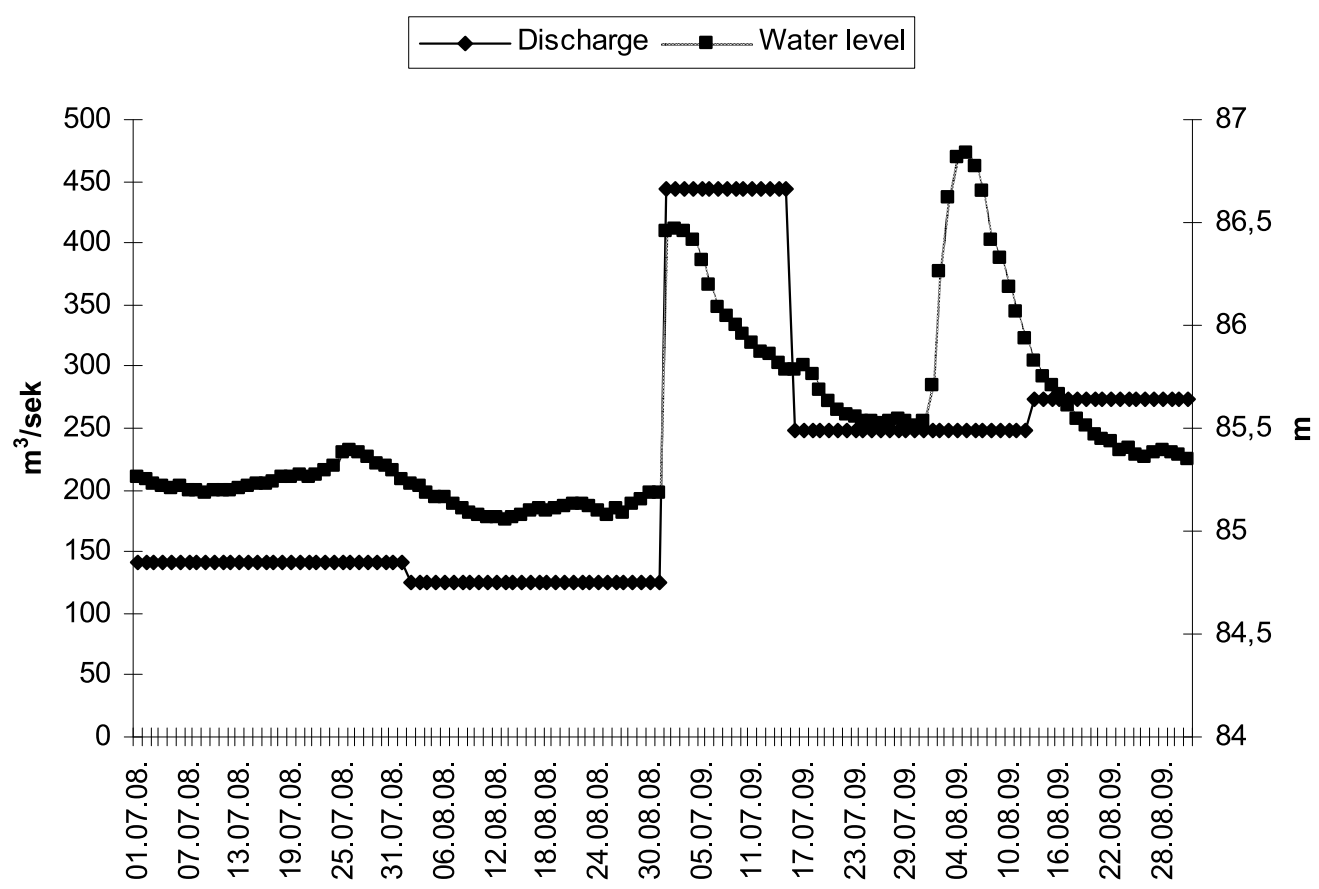

\section{Figure 3}

Water level and discharge recorded during the study period (July and August 2008 and 2009) (after information from the "Latvian Environment, Geology and Meteorology Centre").

\section{Figure 3}

Le niveau d'eau et débits enregistrés au cours de la période d'étude (juillet, août 2008, 2009).

Similar conclusions were also made by other authors. In the Daugava river stretches with similar hydrological conditions the structure of zooplankton is determined by the pollution level. Nevertheless, during periods with a high rate of flow - discharge higher than $1000 \mathrm{~m}^{3} \cdot \mathrm{s}^{-1}$ - changes in the structure of zooplankton communities in the stretches with pollution impact are not recorded (Laganovska, 1963). During the vegetation period of 1991 the water discharge was comparatively higher than in 1980, and the lasting influence of pollution, reflected by decrease in saprobity and changes in the structure of zooplankton communities downstream of the towns, was not recorded (Sprinǵe et al., 1999).

The river water balance in summer 2008 was reduced (Table IV, Figure 3). The mean runoff was $44-99 \%$ of the perennial mean runoff. The water balance of the Daugava in July was $68 \%$, and mean runoff in July was $180 \mathrm{~m}^{3} \cdot \mathrm{s}^{-1}$. The water balance of the Daugava in August was $53 \%$, and mean runoff in August was $140 \mathrm{~m}^{3} \cdot \mathrm{s}^{-1}$. Decrease in the water level in the Daugava continued until the end of June. The period of low water set in the beginning of July (Figure 3). The water temperature at the beginning of August varied between +21 and $+22{ }^{\circ} \mathrm{C}$ (Latvian Environment, Geology and Meteorology Centre, 2008). Therewith the level of dilution of the Daugavpils wastewater downstream of Daugavpils in summer 2008 was low and it had an undesirable impact on zooplankton in general; zooplankton abundance decreased (Figure 4). A positive correlation exists between the water flow rate and characteristic parameters of the organic substances. Among biogenic elements the closest correlation with water flow rate is observed for the $\mathrm{N}_{-} \mathrm{NO}_{3}^{-}$concentration (Kokorite, 2007). Upstream of Daugavpils abundance of zooplankton constituted 63.5 indiv. $\mathrm{L}^{-1}$, while

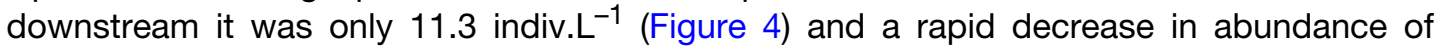
zooplankton occurred exactly at the right bank, where the inflow of wastewater occurred. Also, Kutikova (1976) points out that abundance of zooplankton and decrease in species sensitive to pollution is an indicator for the impact of untoward environmental factors. 


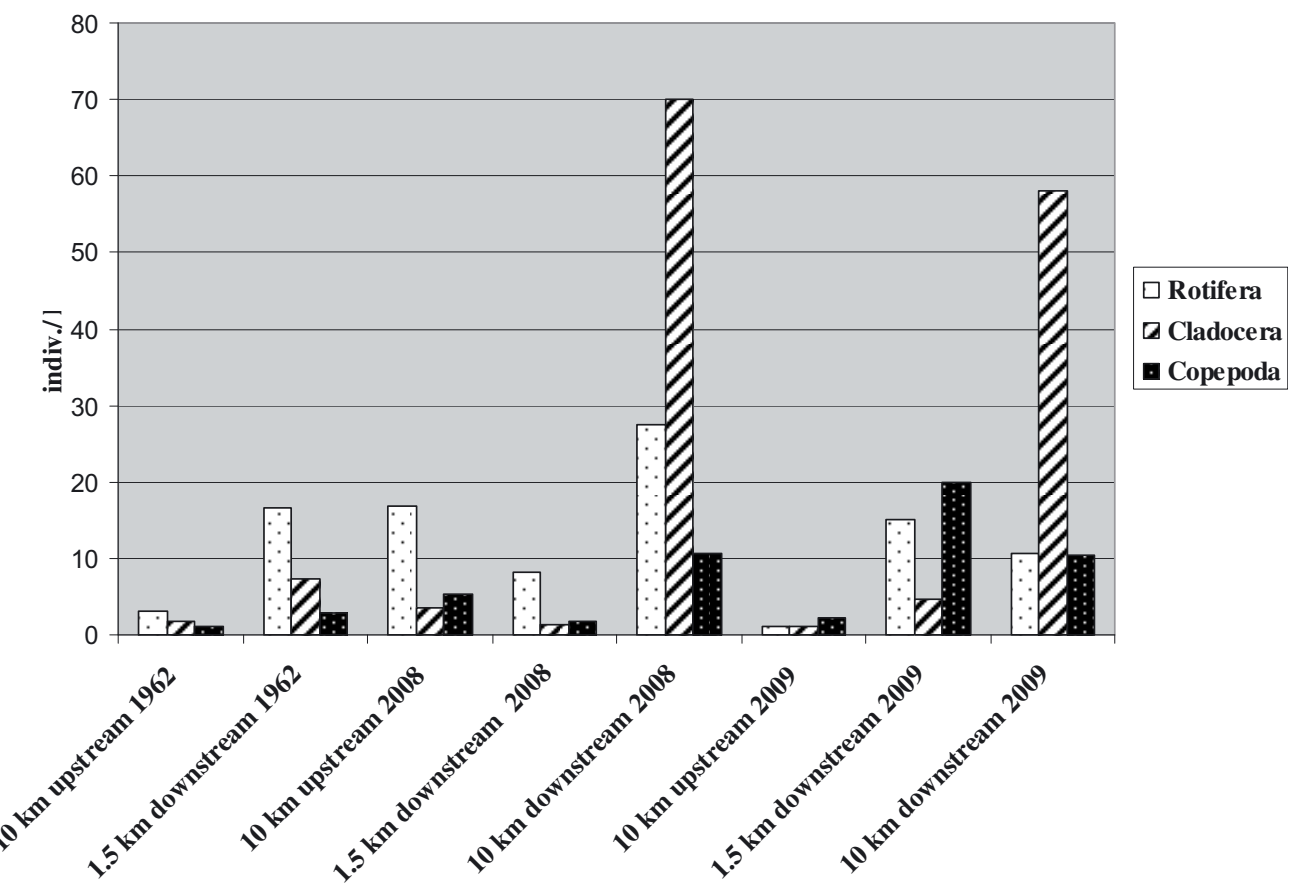

Figure 4

Mean number of zooplankton organisms in 1962, 2008 and $200910 \mathrm{~km}$ upstream, $1.5 \mathrm{~km}$ and $10 \mathrm{~km}$ downstream of the Daugavpils city purification plant.

\section{Figure 4}

Nombre moyen d'organismes du zooplancton en 1962, 2008 et 2009, à $10 \mathrm{~km}$ en amont, à 1,5 km et $10 \mathrm{~km}$ en aval de l'usine d'épuration de la ville de Daugavpils.

Decrease in zooplankton abundance $1.5 \mathrm{~km}$ downstream of Daugavpils occurred not only in predominant species, but there was also a decrease in oligosaprobes or even total extinction thereof: not a single oligosaprobic species was found at the right bank (Figure 5). Only such species as Brachionus quadridentatus $\beta$, Simocephalus vetulus $\beta$, Ceriodaphnia reticulata $\beta$, Keratella quadrata $\beta$ and Brachionus angularis $\alpha-\beta$, as well as Bdelloida increased in numbers. Gulyas (1994) points out that species such as Asplanchna priodonta, Brachionus angularis, B. calyciflorus, B. leydigi, B. quadridentatus, Euchlanis dilatata, Keratella cochlearis, K. quadrata and Polyarthra vulgaris have all been recorded below the mouths of polluted tributaries. The increase in the pollution level causes decrease in numbers of the above-mentioned predominant species, and development of $\beta$ - and $\alpha$ - $\beta$-mesosaprobic species (Bakaeva and Nikonorov, 2006).

Saprobity index at the right bank increased from 1.34 upstream of Daugavpils to 1.79 downstream of Daugavpils, while the Shannon-Wiener index decreased from 5.2 upstream of Daugavpils to 3.6 downstream of Daugavpils, where one species, Brachionus quadridentatus, had taken the predominant role.

Rotifers are less susceptible than cladocerans to the negative effects of high concentrations of pollution (Kirk and Gilbert, 1990). In the study in summer 2008 the zooplankton abundance decreased mainly in Cladocera and Copepoda taxa (Figure 4).

From the results of chemical analysis of the Daugava water in 2008 it is evident that during the vegetation period, when intense processes of taking in substances are going on, concentrations of chemical factors correspond to the Regulations of the Cabinet of Ministers of March 12, 2002, "Regulations Regarding the Quality of Freshwaters and Groundwaters" with amendments made until 04.10.2005 to requirements defined for the waters of 


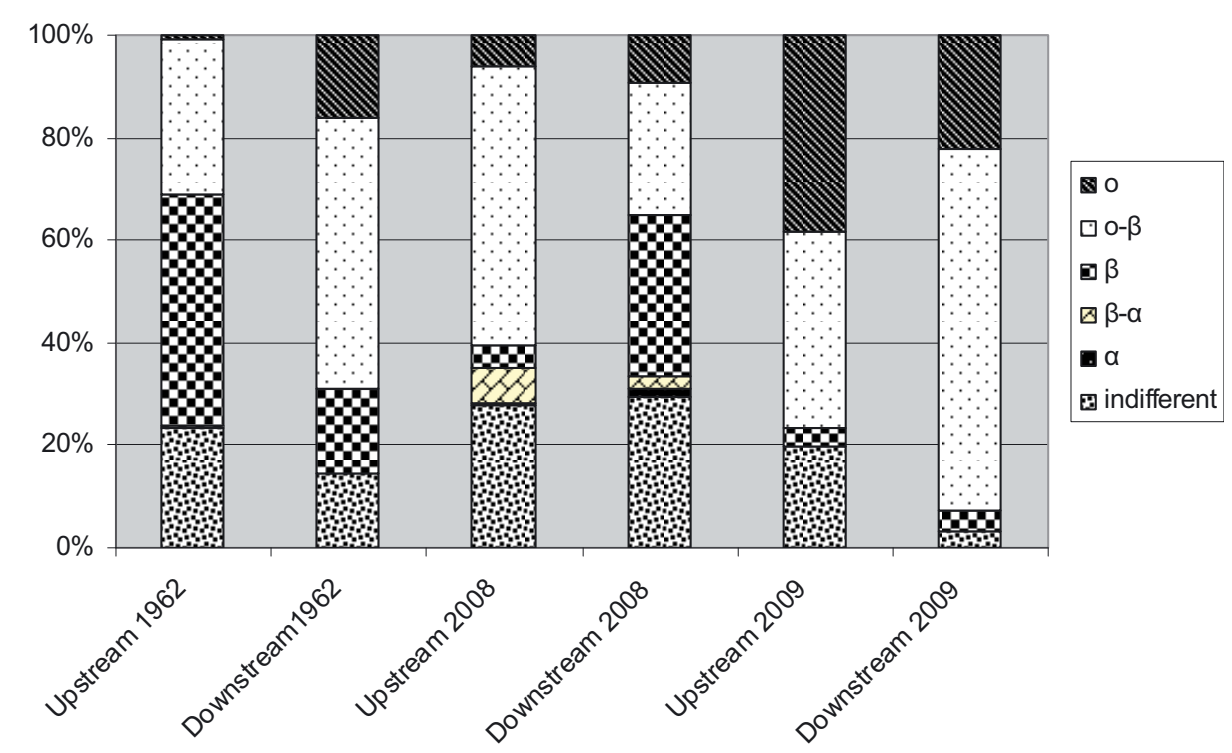

\section{Figure 5}

Percentage division of zooplankton organisms according to saprobity in summer 1962, 2008 and $200910 \mathrm{~km}$ upstream and $1.5 \mathrm{~km}$ downstream of the Daugavpils purification plant.

\footnotetext{
Figure 5

Répartition en pourcentages des organismes du zooplancton selon leur indice saprobie dans l'été 1962, 2008 et 2009, 10 km en amont et 1,5 km en aval de la station d'épuration de Daugavpils.
}

Cypriniformes, and also irregular chemical parameters in general are not raised. Also, according to data from the Belarus 2008 monitoring, the hydrochemical indicators of the Daugava water did not exceed the maximum allowable concentrations (The monitoring of upper waters on the territory of the Republic of Belarus, 2008).

A similar situation, namely when the zooplankton abundance downstream of the Daugavpils purification plant sharply decreased and the biggest decrease occurred the right bank of the river, also occurred in 1964, when there was a decrease in the water balance in summer and also in August 1963, July 1966 and August 1968 (58.5 indiv. $\mathrm{L}^{-1}$ upstream of Daugavpils and 17.6 indiv. $\mathrm{L}^{-1}$-downstream of Daugavpils) (Škute, 1971), in the years when the river water balance level was average (Table IV). According to data collected from 1963 to 1966 in the Daugava river the oligo- $\beta$-mesosaprobic and $\beta$-mesosaprobic species predominated; only in the river section from the city of Daugavpils to Mežciems $(7 \mathrm{~km}$ downstream of the city) did the $\beta$-mesosaprobic and $\beta$ - $\alpha$-mesosaprobic species predominate in zooplankton and right below the collector at the right bank of the river the $\alpha$-mesosaprobic-polysaprobic species joined them (Škute, 1976). During the observation period from 1979 to 1980 in the Daugava River downstream of the Daugavpils wastewater outlets changes in the structure of zooplankton communities were recorded. These changes were reflected by a decrease in diversity of species, and increased significance of the saprobic species Rotatoria neptunia and Rotatoria tridens (Škute and Škute, 1984).

According to the studies carried out in August 1980 the stretch of the river downstream of Daugavpils was characterised by increased saprobity and decreased biological diversity. Dominating species in the potamoplankton communities in the river downstream of Daugavpils were Brachionus calyciflorus and Br. Urceolaris, and in the coastal habitats, Rotaria tardigrada, $R$. Socialis, $R$. Saprobica, Trichocerca cylindrica and Brachionus urceolaris. All of the dominating species in the littoral communities belong to the group of the indicators of $\alpha$-mesosaprobity (Springe et al., 1999). 
During the low water flow periods (in winter and summer) separate sections of the Daugava River 2-8 km downstream of the largest cities are $\alpha$-mesosaprobic. Other sections of the river where is no influence of human activities are characterised by the $\beta$-mesosaprobity level (Matisone, 1965; Auniņš, 1967; Kumsare, 1967).

In similar studies on other large rivers the opinions of authors are divided. Bothár (1988) observed lower maximum densities and different seasonal dynamics patterns downstream of Budapest, Hungary, in the Danube River. According to the author, these differences can be explained by the effects of wastewaters and changed stream conditions due to the regulated riverbed and the side arm of Szentendre. Nevertheless, in Vadadi-Fülöp's (2009) studies in the Danube River upstream and downstream of Budapest, there were no remarkable differences between the upstream and downstream sections, except that the copepod density increased downstream. This does not support the hypothesis that municipal and industrial wastewaters of the capital may have a significant impact on zooplankton communities downstream of Budapest. In the Vistula in Warsaw, Poland, zooplankton species compositions were similar above and below the sewage inflow points, probably because the Vistula is deep and wide (Klimowicz, 1981).

As a rule, with the decrease in eutrophication of a water body the relation indicators of Cladocera to Copepoda ( $\left.N_{\text {Cladocera }} / N_{\text {Copepoda }}\right)$ increase, reflecting the approximate relation of peaceful and predator forms (Andronikova, 1996). In this study this kind of relation was not found. Semenova (2010) points out that the relation of Cladocera number to Copepoda number ( $\left.N_{\text {Cladocera }} / N_{\text {Copepoda }}\right)$ is not very informative.

It is known that in the zooplankton trophic structure in the case of increase in the pollution level the number of organisms supplying themselves with food from the surface increases and the number of organisms supplying themselves with food from the depth decreases (Demenik, 1990; Krylov, 2005, 2006). In the current study this relation is not examined.

$10 \mathrm{~km}$ downstream of the city of Daugavpils the zooplankton abundance and diversity of species increases, which is indicative of the fact that in the Daugava River the process of self-purification is taking place effectively (Figure 4). Similar conclusions were also made by Škute (1976) in her 1962-1972 studies. A number of authors have also reported the importance of zooplankton in the effectiveness of the self-purification process (Kutikova, 1976; Ivanova, 1976b; Bakaeva and Nikonorov, 2006). The effectiveness of the Daugava self-purification is also enabled by its geomorphological factors - river fall, large percentage of meanders, and dolomite or sandy riverbed.

The comparison of data on sites across study years using the Renkonen index proved that similarities are insignificant. Comparing the right bank in places $10 \mathrm{~km}$ upstream of Daugavpils and $1.5 \mathrm{~km}$ downstream of Daugavpils, the similarity between these places in 2009 was bigger than in 2008, when the water level was low and Daugavpils' wastewater had a negative effect on zooplankton communities (Table V).

\section{CONCLUSIONS}

The total taxa number in the Daugava River section of upstream and downstream of Daugavpils has not substantially changed. Relevant changes in the structure of species are reported.

Daugavpils' wastewaters pollute the Daugava River; however, the negative effect of pollution on zooplankton shows up only in years and in seasons with low water level and discharge. The negative effect of wastewaters is expressed as a decrease in the total zooplankton abundance and species diversity according to the Shannon-Wiener index, and increase in saprobity.

$10 \mathrm{~km}$ downstream of Daugavpils the zooplankton abundance and species diversity increases, which is indicative of the fact that the self-purification process in the Daugava River is taking place effectively. 
Table $V$

Establishment of similarity according to the Renkonen index.

Tableau $\mathrm{V}$

Tableau de similitudes selon l'indice Renkonen.

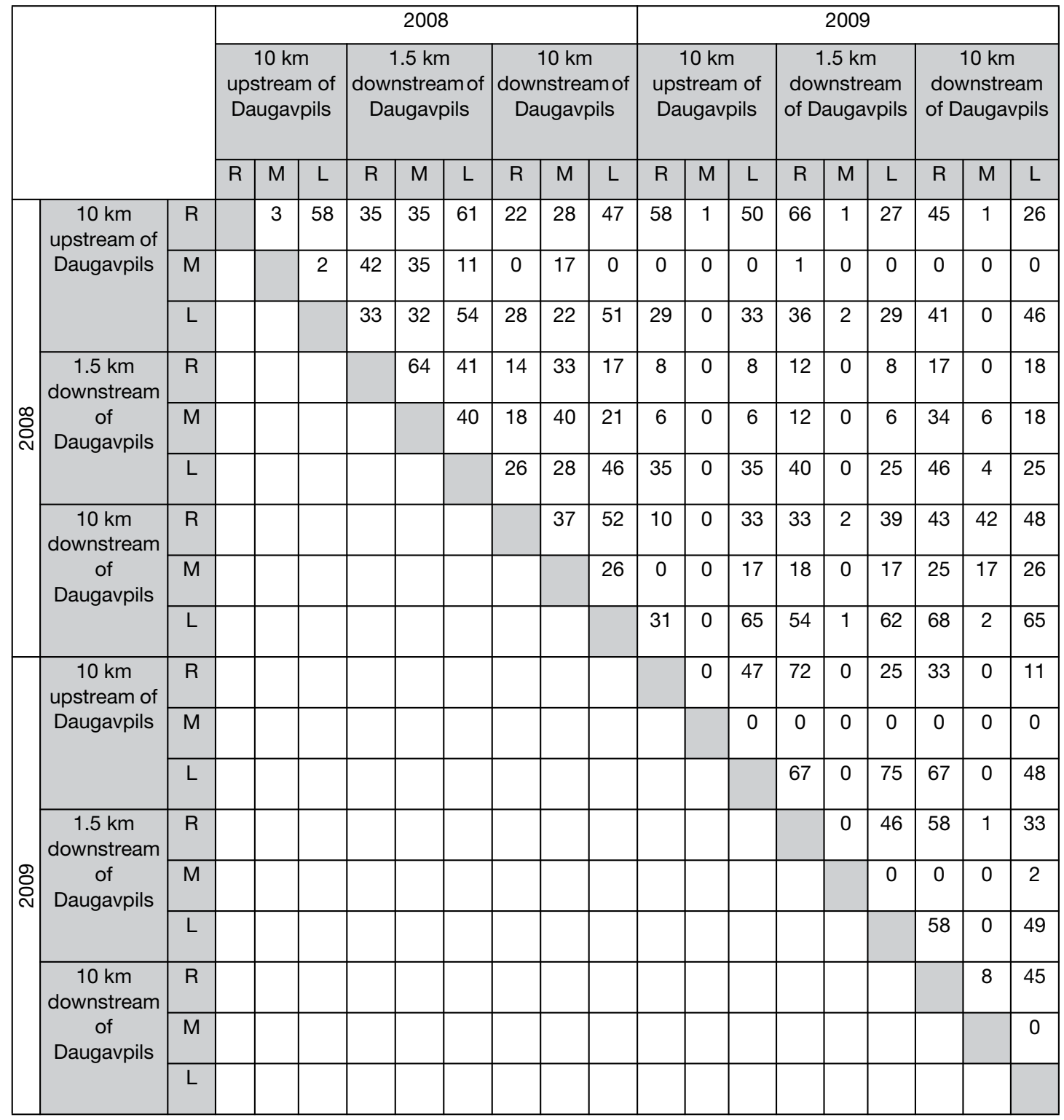

$\mathrm{R}=$ the right bank of the river; $\mathrm{L}=$ the left bank of the river; $M=$ the middle of the river.

\section{ACKNOWLEDGEMENTS}

The present research was supported by the European Social Fund project "Support for the implementation of doctoral studies at Daugavpils University" (Contract number 2009/0140/1DP/1.1.2.1.2/09/IPIA/VIAA/015).
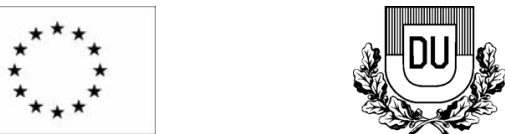


\section{REFERENCES}

Andronikova I.N., 1996. Structural-functional organization of zooplankton in lakes' ecosystem of different trophic types, Nauka, St. Petersburg, 189 p.

Auniňš E.A., 1963. Calculation of ionic-salt run-off and the agrgression of water in the Daugava River. In: Kumsare A.J. (ed.), Hydrobiology and ichthyology of inland waterbodies in the Baltic states, Latvian SSR Academy of Sciences, Riga, 31-46.

Bakaeva E.N. and Nikanorov A.M., 2006. Hydrobionts for the assessment of water quality, Institute of Water Problems, RAS, Nauka, Moscow, 239 p.

Beach N.W., 1960. A study of the planktonic rotifers of the Presque Isle County, Michigan. Ecol. Monogr., 30, 339-357.

Borutsky E.V., 1960. Key to identification of wild freshwater crawfish of the USSR and contiguous countries from fragments in fish intestines, Academy of Sciences of the USSR, Moscow, $218 \mathrm{p}$.

Bothár A., 1988. Results of long-term zooplankton investigations in the River Danube, Hungary. Verhandlung Internationale Vereinigung Limnologie, 23, 1340-1343.

Briede A., Kl̦aviňš M., Rodinovs V. and Kokorite I., 2001. Seasonal and long-term discharge changes in Latvian rivers. Geographical Articles, 9, 20-32.

Briede A., Klavinšs M., Rodinovs V. and Lizuma L., 2004. Ice regime in Latvian rivers. Geographical Articles, 12, 49-55.

Cimdinš P., Druvietis I., Liepa R., Parele E., Urtane L. and Urtans A., 1995. Latvian catalogue of indicator species of freshwater saprobity. Proc. Latv. Acad. Sci., 1/2, 122-133.

Deksne R., Škute A. and Paidere J., 2010. Changes in structure of zooplankton communities in the middle Daugava (western Dvina) over the last five decades. Acta Zool. Litua., 20, 190-208.

Demenik A.L., 1988. Turners as a component of zooplankton communities of rivers' ecosystems, VINITI, Minsk, $54 \mathrm{p}$.

Demenik A.L., 1990. Sedimentation and mineralization of suspended substances in turners' communities in the Neman River. In: Materials of III international conference, Institute of zoology, Leningrad, 22-25.

Escribano R. and Hidalgo P., 2000. Spatial distribution Spatial distribution of copepods in the north of the Humboldt Current region off Chile during coastal upwelling. J. Mar. Biol. Assoc. U.K., 80, 283-290.

Ferdous Z. and Muktadir A.K.M., 2009. A Review: Potentiality of Zooplankton as Bioindicator. Applied Sciences, 6, 1815-1819.

Gruberts D., 2007. Effect of floods on phytoplankton communities in aspect of river monitoring: a case of the Middle Daugava River (South-east Latvia). Arch. Hydrobiol. Suppl., 161, 487-510.

Gruberts D., 2009. The long-termed changes of climate and Daugava stream in Daugavpils. In: LU 67th Scientific conference, Climate changes and water, Works collection, University of Latvia, 68-75.

Gulyas P., 1994. Studies on the rotatorian and crustacean plankton in the Hungarian section of the Danube between 1848.4 and 1659.0 river kilometer. Limnologie Aktuel, I2, 2-14.

Hauer F.R., Baron J.S., Campbell D.H., Fausch K.D., Hostetler S.W., Leavesley G.H., Leavitt P.R., Mcknight D.M. and Stanford J., 1997. Assessment of climate change and freshwater ecosystems of the rocky mountains, USA and Canada. Hydrol. Proc., 11, 903-924.

Hill M.O. 1973. Diversity and evenness: a unifying notation and its consequences. Ecology, 54, 427-432.

Ivanova M.B., 1976a. Influence of pollution on planktonic crustaceans and the possibility of using them for determination of the river pollution. In: Skarlato O.A. (ed.), Methods of bilogical analysis of wreshwaters, Institute of Zoology, Leningrad, 68-80.

Ivanova M.B., 1976b. Experience of participation of planktonic creatures in selfpurifying processes (on the example of zooplankton from the shores of the Izhora River). In: Skarlato O.A. (ed.), Hydrobilogical bases of water selfpurifying, Institute of Zoology, Leningrad, 36-42.

Kavacs G., 1994. Encyclopaedia of Latvia's Nature, Latvian encyclopaedia publishers, Riga, 255 p.

Kḷaviņš M., Nikodemus O., Seglinš̌ V., Melecis V., Vircavs M. and Āboliņa K., 2008. Invironmental science, LU Academical publishing house, Riga, 599 p.

Klimowicz H., 1981. The plankton of the River Vistula in the region of Warsaw in the years 1977-1979. Acta Hydrobiologica, 23, 47-67. 
Kokorīte I., 2007. Chemical content of Latvian overground waters and its influential factors, promotion work's summary, University of Latvia Geographical and ground science faculty, Environmental science department, Riga, $27 \mathrm{p}$.

Kirk K.L. and Gilbert J.J., 1990. Suspended clay and the population dynamics of planktonic rotifers and cladocerans. Ecology, 71, 1741-1755.

Krebs J.C., 1999. Ecological Methodology, 2nd ed., Addison Wesley Longman, Melno Park, California, USA, $620 \mathrm{p}$.

Krylov A.V., 2005. Zooplankton in plain rivers, Nauka, Moscow, 263 p.

Krylov A.V., 2006. The changes in trophical structure of zooplankton water flow due to environmental factors. In: Rumjancev V.A. and Trifonova I.S. (eds.), Report Thesis in the International Conference Bioindication in Monitoring of Freshwaters' ecosystems, St. Petersburg, 81-85.

Kumsare A.J., 1967. Hydrobiology of the Daugava River, Science, Riga, 186 p.

Kurss V. and Stinkule A., 1997. Latvia's minerals, Zvaigzne, Riga, 200 p.

Kutikova L.A., 1970. Rotifera of the USSR fauna. Key to fauna of the USSR, Nauka, Leningrad, $744 \mathrm{p.}$

Kutikova L.A., 1976. Water planktons' turners as the indicator of water quality. In: Kutikova L.A. (ed.), Methods of water biological analysis, Nauka, Leningrad, 80-90.

Laganovska R., 1963. Zooplankton of the river Daugava and peculiarities of its development in connection with hydrological regime and pollution of the river, 10th Freshwater in Baltic Scientific conference, Minsk, $139 \mathrm{p}$.

Latvian Environment, Geology and Meteorology Centre. Available from http://www.meteo.Iv/public/ 27710.html (accessed 8 September 2010).

Lazareva V.I., 2010. Zooplankton Structure and Dynamics in the Rybinsk Reservoir, KMK Scientific Press Ltd., Moscow, $183 \mathrm{p}$.

LU agency "LU Institute of Biology", 2007. The evaluation of ecological situation of the Daugava River, University of Latvia, Salaspils, 58 p.

MacArthur R.H., 1965. Patterns of species diversity. Biol. Rev., 40, 510-533.

Manuilova E.F., 1964. Cladocera of the USSR fauna, Nauka, Moscow-Leningrad, 327 p.

Marneffe Y., Descy J.P. and Thomé J.P., 1996. The zooplankton of the lower river Meuse, Belgium: seasonal changes and impact of industrial and municipal discharges. Hydrobiologia, 319, 1-13.

Mathivanan V., Vijayan P., Sabhanayakam S. and Jeyachitra O., 2007. An assessment of plankton population of Cauvery river with reference to pollution. Environ. Biol., 28, 523-526.

Matisone M., 1965. Biogenic run-off of the Daugava River. In: Kumsare A.J. (ed.), Fishery of the inland warbodies in the Latvian SSR, Science, Riga, 365-379.

Mulani S.K., Mule M.B. and Patil S.U., 2009. Studies on water quality and zooplankton community of the Panchganga river in Kolhapur city. Environ. Biol., 30, 455-459.

Semenova A.N., 2010. Indicating role of zooplankton in the assessement of the ecological condition of Kurshskij Gulf, Autoreport, Borok, 21 p.

Shannon C.E., 1948. Mathematical Theory of Communication. The Bell System Technical Journal., 27, 379-423,623-656.

Sprinǵe G., Briede A., Druvietis I., Parele E., Rodinovs V. and Urtāne L., 1999. Investigations of biodiversity in freshwater ecosystems of Latvia. In: Naimovičiene Ž., Raudiene L. and Virbickas T. (eds.), Hydrobiological research in the Baltic countries, Part I, The rivers and lakes, Institute of Ecology, Vilnius, 232-272.

Škute R.J., 1971. Zooplankton of the River Daugava and its role in the productivity and biological evaluating of the river. Dissertation, Tartu University, Tartu, $233 \mathrm{p}$.

Škute R.J., 1976. Regionalism of the Daugava River according to zooplankton. In: Škute R.J. (ed.), Ecological and Biological Investigations of Water Animals, Zvaigzne, Riga, 43-55.

Škute R.J. and Škute A.O., 1984. Sanitary characteristic of the middle part of the river Daugava. In: Škute R. J. (ed.), Sanitary Characteristic of the River Daugava, DPI, Daugavpils, 38-41.

The Ministry of Environment, 2009. available from http://www.vidm.gov.Iv/lat/informacija_presei/ preses_relizes/?doc=954715.09.2009 (accessed 17 December 2009).

The monitoring of upper waters on the territory of the Republic of Belarus, 2008. Results of the investigation 2008, Department of Hydrology of the Belarus SSR, Belarus, $37 \mathrm{p}$. 
The summary of overground waters' quality, 2003. Latvian Environment, Geology and Meteorology Centre (on line), available from http://www.meteo.Iv/produkti/sowq_Iv/2003/ (accessed 3 February 2010).

Vadadi-Fülöp C.S., 2009. Zooplankton (Cladocera, Copepoda) dynamics in the River Danube upstream and downstream of Budapest, Hungary. Opusc. Zool. Budapest, 40, 87-98.

Vandish O.I., 2000. Zooplankton as indicator of lake ecosystems' conditions (on the example of subartcical lake Imandra). Water Resour., 27, 364-371.

Vanjare A.I., Padhye S.M. and Pai K., 2010. Zooplankton from a polluted river, Mula (India), with record of Brachionus rubens (Ehrenberg, 1838) epizoic on Moina macrocopa (Straus, 1820). Opusc. Zool. Budapest., 41, 89-92.

Whitton B.A. (ed.), 1975. River Ecology. Studies in Ecology, Volume 2, Blackwell Scientific Publications, US distributors, University of California Press, Berkeley, Oxford, 725 p. 